\title{
Growth and nutritional diagnosis of Rosemary plants submitted to nitrogen and sulfate fertilization
}

\author{
'State University of Santa Cruz, Ilhéus, Brazil \\ ${ }^{2}$ Federal University of Recôncavo da Bahia, Cruz das Almas, Brazil \\ ${ }^{3}$ State University of Feira de Santana, Feira de Santana, Brazil \\ ${ }^{*}$ Corresponding author, e-mail: eng.alinesouza@gmail.com
}

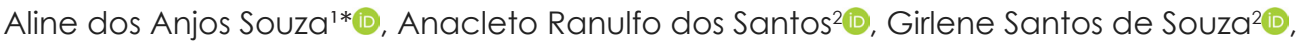
Railda Santos de Jesus ${ }^{3}\left({ }^{\circ}\right.$, Janderson do Carmo Lima ${ }^{3}$, Uasley Caldas de Oliveira ${ }^{3}$

\begin{abstract}
Studies on the cultivation of medicinal plants are of relevance to the population since they are primary sources of medication. Among these plants stands out the rosemary (Rosmarinus officinalis L.) for having diverse therapeutic properties. The objective of this work was to evaluate the initial growth and nutritional status of rosemary plants grown with different co'ncentrations of nitrogen and sulfur. The treatments were distributed in a $4 \times 2$ factorial scheme with four nitrogen doses: 105, 210, 315, and $420 \mathrm{mg} \mathrm{L}^{-1}$ of nitrogen combined with two sulfur doses: 32 and $64 \mathrm{mg} \mathrm{L}^{-1}$ with seven replications totaling 56 experimental units. The seedlings were obtained through asexual propagation (cuttings), originating from parent plants. The experimental units were arranged in a completely randomized design. Growth evaluations were carried out at 120 days of cultivation, using: plant height (HT) stem diameter (DS), root dry matter mass (RDM), stem dry matter mass (SDM), mass leaf dry matter (LDM), total dry matter (TDM), shoot dry matter mass (SDMS). The data obtained were subjected to analysis of variance and depending on the level of significance in the F test, the study was carried out using the means test (Tukey 5\%). The agronomic characteristics (HT), (DS), (RDM) and (MDMAP) were significant for N. Only (RDM) showed significant interaction for the doses of $\mathrm{N}$ and $\mathrm{S}$. The dose $420 \mathrm{mg} \mathrm{L}^{-1}$ promoted the highest concentrations in the components leaf and stem. The lowest dose $105 \mathrm{mg} \mathrm{L}^{-1}, \mathrm{~N}$ promoted the highest concentrations of $\mathrm{S}$ in the leaf and stem. The assimilation of $\mathrm{S}$ by the rosemary plants was dependent on the doses of $\mathrm{N}$.
\end{abstract}

Keywords: medicinal plants, mineral plant nutrition, Rosmarinus officinalis L.

\section{Introduction}

Rosemary (Rosmarinus officinalis L.) belongs to the Lamiaceae family, originally from the Mediterranean region of Europe, has been cultivated in almost all countries with a tropical climate, including Brazil (Malaquias et al., 2014). This plant has a woody sub-shrub size, can reach up to $1.5 \mathrm{~m}$ in height. Its leaves are small, linear, leathery, opposite, lanceolate and very aromatic, with small light bluish flowers, and with a strong and pleasant aroma. It is also known as: alecrim de horta, alecrim de jardim, ervacoada, erva-de-graça, rosma-marinha and rosmarino (Lorenzi \& Matos, 2006).

Characterized as a colorless or pale yellow liquid with a characteristic odor rosemary essential oil stands out in various sectors of the industry, possessing many medicinal properties, being used in food preservation, fragrance development and aromatherapy due to its antioxidant and antimicrobial activity (Rašković et al.,
2014)

It is widely used for both food and herbal purposes, studies with rosemary in the literature are still scarce, especially in relation to their nutritional requirements. To achieve satisfactory yields of plant material and active ingredients, knowing the proper management is of relevance, since the external stimuli of the environment will influence the production indexes and quality (Ehlert et al., 2013).

Among the essential elements for the good performance of crops, we have nitrogen, used in fertilization to enhance the production of biomass, since it is responsible for cell expansion, resulting in the development of the plant area, also exercising the function of essential constituent of pigments and proteins, which have an important influence on physiological processes (Taiz et al., 2017). Like nitrogen, sulfur plays a similar role in the function of numerous compounds, such 
as amino acids, proteins, coenzymes, among others, in addition to processes of cell differentiation, ionic absorption and hormonal control (Stipp \& Casarin, 2010).

Because of this, the relationship between them has become the object of study aiming to correlate it with plant growth and development. Studies such as BonfimSilva \& Monteiro (2007), obtained positive results in grass production as a function of combined doses of $\mathrm{N}$ and $\mathrm{S}$.

Silva \& Trevizam (2015) when evaluating the ionic interaction between $\mathrm{N}$ and $\mathrm{S}$ and their effects on plant nutrition found that greater knowledge of these interactions can contribute to the compression of the dynamics in the soil and in the plant and, therefore, obtain an increase in crop productivity.

Thus, the $\mathrm{N}$ and $\mathrm{S}$ interaction must be taken into account in the fertilization recommendations. Because most of the $\mathrm{N}$ in plants is in the form of proteins and sulfur as cysteine and methionine. In case of deficiency of these elements there will be a decrease in the production of these amino acids and the proteins that contain them will not be formed (Marschner, 2012).

The use of concentrated fertilizer formulas, without the addition of $S$, results in the low utilization of nitrogen fertilizer, therefore the combination of $\mathrm{N}$ and $\mathrm{S}$ should be considered in the fertilization programs (Cantarella, 2007). In view of the above, the aim of this study was to evaluate the combination of nitrogen and sulfur doses in the growth and nutritional diagnosis of rosemary plants.

\section{Material and Methods}

The experiment was conducted in a greenhouse located on the experimental farm of the Center for Agrarian, Environmental and Biological Sciences of the Federal University of Recôncavo da Bahia in the municipality of Cruz das Almas-BA, which is geographically located at $12^{\circ} 40^{\prime} 19^{\prime \prime} \mathrm{S}$ and $39^{\circ} 06^{\prime} 22^{\prime \prime} \mathrm{W}$ at an altitude of $212 \mathrm{~m}$. The local climate is classified as hot and humid tropical, Aw to Am, according to the classification of Köppen-Geiger (Alvares et al., 2013), with an average temperature of $23.0^{\circ} \mathrm{C}$ per year and average annual rainfall of $1,136 \mathrm{~mm}$.

The soil used to perform the experiment was classified as a dystrophic Argisol (Ericsson \& Ronge, 2006). Plastic vessels with a capacity of $3.0 \mathrm{~L}^{-1}$ were filled with soil collected in the 0.0 to $0.20 \mathrm{~m}$ depth layer, where analyses of chemical (Table 1) and textural attributes were performed, with values of $80.23 \%$ for sand, $15.30 \%$ for clay and $4.47 \%$ for silt.

Table 1. Chemical attributes of the Argisol used for the cultivation of Rosemary at a depth of $0.0-20 \mathrm{~cm}$, Cruz das Almas, BA, 2019.

\begin{tabular}{|c|c|c|c|c|c|c|c|c|c|c|c|c|c|}
\hline Prof. & $\mathrm{pH}$ & $P$ & K & $S$ & $\mathrm{Ca}$ & $\mathrm{Mg}$ & $\mathrm{Al}$ & $\mathrm{Na}$ & $\mathrm{H}+\mathrm{Al}$ & SB & CTC & $\mathrm{V}$ & M.O \\
\hline & $(\mathrm{cm})$ & $\mathrm{H}_{2} \mathrm{O}$ & $\ldots . . . r$ & ${ }^{-1} \ldots \ldots . .$. & & 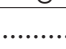 & $\ldots . .$. & $\mathrm{Dl}_{\mathrm{C}} \mathrm{L}^{-1}$. & 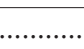 & & $\%$ & $\mathrm{~g} \mathrm{Kg}$ & \\
\hline $0.0-20$ & 5.6 & 0.1 & 7.32 & 2.6 & 0.8 & 0.5 & 0.0 & 0.00 & 1.5 & 1.2 & 2.82 & 47 & 0.96 \\
\hline
\end{tabular}

The experimental design was completely randomized in a $4 \times 2$ factorial scheme, with four nitrogen doses: 105, 210, 315, and $420 \mathrm{mg} \mathrm{L}^{-1}$ and two sulfur doses: 32 and $64 \mathrm{mg} \mathrm{L}^{-1}$, with seven replications totaling 56 experimental units. The following doses of micronutrients were applied to each vessel: boron $(B)=0.81 \mathrm{mg} \mathrm{L}^{-1}$ of $\mathrm{H}_{3} \mathrm{BO}_{3}$; copper $(\mathrm{CU})=1.33 \mathrm{mg} \mathrm{L}{ }^{-1}$ of $\mathrm{CuSO}_{4} \cdot 5 \mathrm{H}_{2} \mathrm{O}$; molybdenum $(\mathrm{MO})=0.15 \mathrm{mg} \mathrm{L}-1$ of $\left(\mathrm{NH}_{4}\right) 6 \mathrm{MO}_{7} \mathrm{O}_{24} \cdot 4 \mathrm{H}_{2} \mathrm{O}$; manganese $(\mathrm{Mn})=3.66 \mathrm{mg} \mathrm{L} \mathrm{L}^{-1}$ of $\mathrm{MnCl}_{2} \cdot \mathrm{H}_{2} \mathrm{O}$ and zinc $(\mathrm{Zn})=4.0 \mathrm{mg} \mathrm{L} \mathrm{L}^{-1}$ of $\mathrm{ZnSO}_{4} \cdot 7 \mathrm{H}_{2} \mathrm{O}$. The concentration of each nutrient was provided via complete and modified nutrient solutions according to (Hoagland \& Arnon, 1950) (Table 2).

Table 2. Volume $(\mathrm{mL})$ of stock solutions to form $1 \mathrm{~L}^{-1}$ of modified nutrient solution, using combinations of nitrogen and sulfur according to the respective treatments.

\begin{tabular}{|c|c|c|c|c|c|c|c|c|c|}
\hline \multicolumn{3}{|c|}{ Stock solution } & \multicolumn{7}{|c|}{ Doses of (N:S) } \\
\hline$(1 \mathrm{M})$ & $105 / 64$ & $105 / 32$ & $210 / 64$ & $210 / 32$ & $315 / 64$ & $315 / 32$ & $420 / 64$ & $420 / 32$ & \\
\hline $\mathrm{KH}_{2} \mathrm{PO}_{4}$ & 1 & 1 & 1 & 1 & 1 & & 1 & 1 & 1 \\
\hline $\mathrm{KNO}_{3}$ & 5 & 5 & 5 & 5 & 5 & & 5 & 5 & 5 \\
\hline $\mathrm{Ca}\left(\mathrm{NO}_{3}\right)_{2}$ & 1.25 & 1.25 & 5 & 5 & 5 & & 5 & 5 & 5 \\
\hline $\mathrm{Mg} \mathrm{SO}_{4}$ & 2 & 1 & 2 & 1 & 2 & & 1 & 2 & 1 \\
\hline $\mathrm{CaCl}_{2}$ & 3.75 & 3.75 & 0 & 0 & 0 & & 0 & 0 & 0 \\
\hline $\mathrm{MgCl}_{2}$ & 0 & 1 & 0 & 1 & 0 & & 1 & 0 & 1 \\
\hline $\mathrm{NH}_{4} \mathrm{NO}_{3}$ & 0 & 0 & 0 & 0 & 3.75 & & 3.75 & 7.5 & 7.5 \\
\hline Micronutrients & 1 & 1 & 1 & 1 & 1 & & 1 & 1 & 1 \\
\hline Ferric EDTA & 1 & 1 & 1 & 1 & 1 & & 1 & 1 & 1 \\
\hline
\end{tabular}


Table 2. Volume (mL) of stock solutions to form $1 \mathrm{~L}^{-1}$ of modified nutrient solution, using combinations of nitrogen and sulfur according to the respective treatments

The rosemary seedlings were obtained by cuttings from plants grown in nurseries and produced in polyethylene plastic bags with $1.0 \mathrm{~L}^{-1}$ of substrate $(70 \%$ soil $+30 \%$ earthworm humus). The most homogeneous seedlings were selected and transferred to the pots, where they remained for a period of 120 days.

The plants were harvested at 120 days and the following agronomic characteristics were evaluated: plant height $(\mathrm{HT})$, using a millimeter ruler, measuring from the neck to the apical meristem, the stem diameter (DS), using a digital caliper. Subsequently, the vegetable components were separated into leaves, stems and roots, which were packed in paper bags, identified and taken to a forced air circulation oven at $45^{\circ} \mathrm{C}$ until reaching constant weight to determine the root dry matter mass (RDM), stem dry matter mass (SDM), leaf dry matter mass (LDM) and total dry matter mass (TDM) for determining growth variables according to the plant growth analysis manual (Benicasa, 2004).

After drying, the samples were ground in a standard Willy mill with a 20 mesh screen. $0.1 \mathrm{~g}$ of the dry matter weight of the leaves, stem and root were weighed on an analytical balance and subjected to acid digestion as described in (Jones, 2001; Silva, 2009). The digested material was diluted to $100 \mathrm{~mL}$ with distilled water, obtaining the extract for the analysis of nitrogen
$(\mathrm{N})$, phosphorus (P) and potassium (K). Nitrogen was determined by the spectrophotometric method of phenolhypochlorite (Weatherburn, 1967), potassium by flame photometry and phosphorus by the spectrophotometric method of molybdate-vanadate (Faithfull, 2002). The $S$ content was determined by the turbidimetric method according to (Silva, 2009).

The results were submitted to statistical analysis of variance, and as a function of the significance level by the F test, for doses of nitrogen, sulfur and their interaction, the Tukey means test at $(p<0.05)$ of probability (Ferreira, 2008) was performed. It is noteworthy, as this study did not adopt dose 0 , the ideal dose of $\mathrm{N}$ for rosemary plants at this stage of growth is in the range of 0 to $105 \mathrm{mg} \mathrm{L}^{-1}$.

\section{Results and Discussion}

From the analyses carried out, there were differences in the level of ( $p \leq 0.05$ and 0.01 ) for the following agronomic characteristics: plant height, mass of dry matter of stem, mass of dry matter of root, and mass of total dry matter. Significant interaction with variations in nitrogen and sulfur doses was observed only for root dry matter mass (Table 3). It was found that the variables stem diameter and dry matter weight of leaves were not influenced by the treatments studied.

The height of the rosemary plants varied with increasing nitrogen doses. The dose that provided the highest height was $105 \mathrm{mg} \mathrm{L}^{-1}$ of $\mathrm{N}$ with $64 \mathrm{mg} \mathrm{L}^{-1} \mathrm{~S}$ where the plants grew on average $44 \mathrm{~cm}$ (Table 4).

Table 3. Summary of analysis of variance with respective mean squares for the variables: plant height (HT), stem diameter (DS), leaf dry matter mass (LDM), stem dry matter mass (SDM) and root dry matter mass (RDM), of rosemary plants cultivated with nitrogen and sulfur doses in a greenhouse, Cruz das Almas, BA, 2019.

\begin{tabular}{|c|c|c|c|c|c|c|c|}
\hline Sources of Variation & $\begin{array}{l}\mathrm{HT} \\
(\mathrm{cm})\end{array}$ & $\begin{array}{c}\text { DS } \\
(\mathrm{mm})\end{array}$ & LDM & SDM & RDM & SDMS & TDM \\
\hline Nitrogen $(a)$. & $181.64^{* *}$ & $0.9261^{\text {ns }}$ & $0.2319^{\text {ns }}$ & $0.8804^{* *}$ & $0,0084^{* *}$ & $5.3396^{* *}$ & $18.1814^{*}$ \\
\hline Sulfur(b) & $4.5714^{\mathrm{ns}}$ & $0.5157^{\text {ns }}$ & $0.4029^{\text {ns }}$ & $0.9991^{*}$ & $0,9205^{\mathrm{ns}}$ & $0.3317^{\text {ns }}$ & $1.7466^{\mathrm{NS}}$ \\
\hline Interaction (a*b) & $9.6666^{\mathrm{ns}}$ & $0.7881^{\mathrm{ns}}$ & $0.5112^{\mathrm{ns}}$ & $0.1506^{\mathrm{ns}}$ & $3.3474^{*}$ & $4.0830^{n s}$ & $22.5030^{N S}$ \\
\hline CV\% & 10.54 & 8.54 & 12.22 & 12.57 & 21.58 & 16.46 & 16.65 \\
\hline
\end{tabular}

Table 4. Plant height (HT), stem matter mass (RDM), root dry matter mass (SDM), shoot dry matter mass (SDMS) and total plant dry matter mass (TDM) of rosemary (Rosmarinus officinalis L.) cultivated with different doses of Nitrogen and Sulfur Cruz das Almas-BA, 2019.

\begin{tabular}{llllll}
\hline Doses N and S & $\begin{array}{l}\text { HT } \\
(\mathrm{cm})\end{array}$ & SDM & RDM & SDMS & TDM \\
\hline $105: 64$ & $44.0 \mathrm{a}$ & $3.73 \mathrm{a}$ & $4.35 \mathrm{ab}$ & $7.67 \mathrm{ab}$ & $11.99 \mathrm{~b}$ \\
$105: 32$ & $43.8 \mathrm{a}$ & $3.48 \mathrm{ab}$ & $4.32 \mathrm{~b}$ & $8.33 \mathrm{a}$ & $12.68 \mathrm{~b}$ \\
$210: 64$ & $36.4 \mathrm{~b}$ & $3.65 \mathrm{ab}$ & $5.18 \mathrm{a}$ & $7.28 \mathrm{~b}$ & $12.88 \mathrm{ab}$ \\
$210: 32$ & $38.1 \mathrm{ab}$ & $3.11 \mathrm{ab}$ & $4.84 \mathrm{a}$ & $8.32 \mathrm{a}$ & $13.75 \mathrm{a}$ \\
$315: 64$ & $42.0 \mathrm{a}$ & $3.39 \mathrm{ab}$ & $4.54 \mathrm{a}$ & $7.57 \mathrm{ab}$ & $12.34 \mathrm{~b}$ \\
$315: 32$ & $40.0 \mathrm{ab}$ & $3.16 \mathrm{ab}$ & $4.79 \mathrm{a}$ & $8.08 \mathrm{ab}$ & $13.36 \mathrm{a}$ \\
$420: 64$ & $35.0 \mathrm{c}$ & $3.01 \mathrm{~b}$ & $5.24 \mathrm{a}$ & $7.34 \mathrm{ab}$ & $12.52 \mathrm{~b}$ \\
$420: 32$ & $37.1 \mathrm{ab}$ & $2.98 \mathrm{~b}$ & $3.50 \mathrm{c}$ & $5.96 \mathrm{c}$ & $8.46 \mathrm{c}$ \\
\hline
\end{tabular}


The lowest height was observed at the dose 420 $\mathrm{mg} \mathrm{L}^{-1}$ of $\mathrm{N}$ and $64 \mathrm{mg} \mathrm{L}^{-1}$ of $\mathrm{S}$, where the plants grew on average $35 \mathrm{~cm}$ characterizing a reduction of $20.45 \%$. Comparing the $\mathrm{N}$ : S ratios with the lowest dose of $105 \mathrm{mg}$ $\mathrm{L}^{-1}$ of $\mathrm{N}$ with $64 \mathrm{mg} \mathrm{L}^{-1}$ corresponds to an $\mathrm{N}$ and $\mathrm{S}$ ratio of 1 ; 0.64 and the dose $420 \mathrm{mg} \mathrm{L}^{-1}$ of $\mathrm{N}$ with $64 \mathrm{mg} \mathrm{L}^{-1}$, at 6:0.56. In order for the 6: 0.56 ratio not to have a negative effect on the height of rosemary plants, it would be necessary to increase the sulfur supply to $256 \mathrm{mg} \mathrm{L}^{-1}$, thus obtaining the ideal ratio of $N$ and $S$, corresponding to 1:62 for this agronomic characteristic.

Generally, in most cases, a higher nitrogen supply brings positive responses in plant growth. In the case of this study, the addition of $\mathrm{N}$ had the opposite effect, since the sulfur supply was insufficient, which may have interfered with the efficiency of nitrogen absorption.

May et al. (2010) also obtained the same result of plant growth in the evaluation of phytomass and essential oil production of Mentha citrata as a function of nitrogen fertilization, because nitrogen has a direct relationship with the photosynthetic capacity of plants. Therefore, the supply in adequate quantities provides its greatest growth.

For the variable stem dry matter mass (SDM) the highest yield of stem dry matter obtained was 3.73 $\mathrm{g}$ corresponding to a dose of $105 \mathrm{mg} \mathrm{L}^{-1}$ of $\mathrm{N}$, and the lowest was $2.98 \mathrm{~g}$ for the $420 \mathrm{mg} \mathrm{L}^{-1}$ dose of $\mathrm{N}$, promoting a reduction of $8 \%$. Comparing the variation of $\mathrm{S} 64 \mathrm{mg}$ $\mathrm{L}^{-1}$ and $32 \mathrm{mg} \mathrm{L}^{-1}$ in relation to the highest and lowest $\mathrm{N}$ dose, the mass reductions were 14 and $11 \%$ respectively (Table 4).

Liu et al. (2009) corroborate the results found where they verified no interaction between $\mathrm{N}$ and $\mathrm{S}$ in the cultivation of Chinese chives, however, this crop was responsive to the nutrients treated in isolation, corroborating the results found with rosemary.

The results obtained for root dry matter mass demonstrated a significant effect for the doses of $\mathrm{N}$ and on the interaction between $\mathrm{N}$ and $\mathrm{S}$. The best result found for this variable was for the treatment $420 \mathrm{mg} \mathrm{L}^{-1} \mathrm{~N}$ and 64 $\mathrm{mg} \mathrm{L}^{-1} \mathrm{~S}$ with a yield of $5.24 \mathrm{~g}$, compared with the lowest result corresponding to $420 \mathrm{mg} \mathrm{L}^{-1} \mathrm{~N}$ and $32 \mathrm{mg} \mathrm{L}^{-1} \mathrm{~S}$ with $3.50 \mathrm{~g}$, with a reduction of $33.2 \%$ (Table 4).

The evaluation of roots in plant growth has relevance, because it is through them that water and nutrients are absorbed by plants. Peixoto et al. (2011) pointed out that roots are an important component to be considered in the evaluation of total plant growth, especially when they are related to economic production.

Silva et al. (2013) when studying nitrogen doses in wheat crop obtained a significant increase in root dry mass with maximum production at the nitrogen dose of $54.44 \mathrm{mg} \mathrm{L}^{-1}$. Studying nitrogen and sulfur interaction in brachiaria grass (Brachiaria decumbens), Silveira et al. (2011) obtained a significant effect isolated from nitrogen fertilization in the production of dry root mass, where the results were adjusted to the quadratic model. Ciriello et al. (2014) verifying increasing doses of nitrogen fertilizer in the form of urea $\left(0,40,80,120\right.$, and $\left.160 \mathrm{mg} \mathrm{L}^{-1}\right)$ in the initial growth of guanandi (Calophyllum brasiliense Cambèss), observed that the lowest dose, $40 \mathrm{mg} \mathrm{L}^{-1}$, was responsible for the greater accumulation of root biomass of these seedlings. For rosemary, root growth had different responses to the doses of $S$ used, with the best dose being $210 \mathrm{mg} \mathrm{L}^{-1}$ of $\mathrm{N}$, where the maximum point was found corresponding to $239.17 \mathrm{mg} \mathrm{L}^{-1}$ combined with $62 \mathrm{mg} \mathrm{L}^{-1}$ $S$, respectively.

Following the same reasoning, the results for shoot dry matter mass obtained the highest mean for 105 $\mathrm{mg} \mathrm{L}^{-1}$ dose of $\mathrm{N}$ with $32 \mathrm{mg} \mathrm{L}^{-1}$ of $\mathrm{S}$ with yield $8.33 \mathrm{~g}$ and lowest $420 \mathrm{mg} \mathrm{L}^{-1}$ of $\mathrm{N}$ with $64 \mathrm{mg} \mathrm{L}^{-1}$ of $\mathrm{S}$ with $5.96 \mathrm{~g}$, with a reduction of $28.4 \%$. Comparing the highest and lowest doses of $\mathrm{N}$ as a function of the variation in the doses of $\mathrm{S}$ 64 and $32 \mathrm{ha}$, there was a reduction of $8 \%$ to 105 and 18 $\%$ to 420 , respectively.

May et al. (2010) evaluating the production of accumulated dry mass of the aerial part of $M$. citrata as a function of increasing nitrogen doses observed that the highest doses promoted increases in the accumulated dry mass of the aerial part, with an increase of $32 \%$ in the dry mass produced with application of $200 \mathrm{~kg} \mathrm{ha}^{-1}$ of $\mathrm{N}$ compared to non-application of nitrogen, going from 4,856 to $6,420 \mathrm{~kg} \mathrm{ha}^{-1}$ of dry mass between the lowest and highest doses, respectively.

Plants generally respond well to nitrogen fertilization. However, excess $N$ is harmful; therefore, the dose supplied to the crop should be well balanced in relation to the amount of other nutrients, including sulfur. The studied species showed low nitrogen need at this stage of its growth, and the lowest dose provided (105 $\mathrm{mg} \mathrm{L}^{-1}$ ) was sufficient for a good dry matter yield of the plant.

The results found for total dry matter mass of the plants indicate that the highest mean was for dose at 210 $\mathrm{mg} \mathrm{L}^{-1}$ of $\mathrm{N}$ with $32 \mathrm{mg} \mathrm{L}^{-1} \mathrm{~S}$ with $13.75 \mathrm{~g}$ and the lowest $420 \mathrm{mg} \mathrm{L}^{-1} \mathrm{~N}$ with $32 \mathrm{mg} \mathrm{L}^{-1} \mathrm{~S}$ had a yield of $8.46 \mathrm{~g}$ and produced a reduction of $38.4 \%$. Comparing the highest and lowest dose of $\mathrm{N}$ as a function of the variation of doses $64 \mathrm{mg} \mathrm{L}^{-1}$ and $32 \mathrm{mg} \mathrm{L}^{-1}$ of $\mathrm{S}$, there was a reduction of $4.2 \%$ for 105 and $33 \%$ to 420 , respectively. 
The total dry matter mass of the plant is an important data, because through the results, one has a notion of the level of photosynthetic efficiency of the leaves, and from this evaluates its contribution in plant growth.

Mastucello et al. (2018) evaluating Panicum maximum BRS Quênia grass production in relation to the increase in $\mathrm{N}$ doses observed that the efficiency of $\mathrm{N}$ decreased as the fertilizer dose increased from 14.7 to $27.97 \%$ for total dry matter mass, showing similarity with the results found for rosemary. It is worth noting that these results do not occur frequently, since there are several studies that affirm that the greater mass production of the dry matter of the plants occurs due to the increase in the dose of $\mathrm{N}$, because of the participation of the associated element in the acceleration of the growth rate, acting as a controlling factor of the different growth and development processes of the plants, providing an increase in phytomass by carbon fixation.

Freitas et al. (2012) working with Passiflora alata, obtained an increase in dry phytomass with the increase of $\mathrm{N}$ doses up to a maximum dose, followed by a decrease in subsequent doses. Binotti et al. (2010) working with the sources of $\mathrm{N}$, urea, ammonium sulfate and the mixture 50 $\%$ urea $+50 \%$ ammonium sulfate at the dose of $80 \mathrm{~kg}$ $\mathrm{ha}^{-1}$ of $\mathrm{N}$ also found increments of $9 \% ; 20 \%$ and $22 \%$ respectively in the dry mass of bean plants.

In this study with rosemary plants, the increase in doses caused the opposite effect, demonstrating that the plant was not responsive to the treatments used, which may be related to the nutritional requirement and the acclimatization conditions of the vegetable.

The results expressed from the mean squares obtained for nutritional diagnosis, show that there was a significant effect of the levels of $N, P, K$ and $S$, depending on the doses of $\mathrm{N}$ and $\mathrm{S}$ (Table 5). The levels of $\mathrm{N}$ were significant for the leaf and stem components, $\mathrm{P}$ for leaf, and $\mathrm{S}$ for all plant components. The interaction between the doses of $\mathrm{N}$ and $\mathrm{S}$, showed significance only for the stem component. The levels of $K$ in the leaf and stem were not significant due to the doses of $\mathrm{N}$ and $\mathrm{S}$ used.

Table 5. Summary of analysis of variance with respective mean squares for the variables: nitrogen (N), sulfur (S), phosphorus (P) and potassium (K) of the leaf, stem, root in plants of Rosemary (Rosmarinus officinalis L.) grown with different doses of nitrogen and sulfur Cruz das Almas-BA, 2019.

\begin{tabular}{|c|c|c|c|c|c|c|}
\hline \multirow{3}{*}{$\begin{array}{c}\text { Sources of } \\
\text { variation }\end{array}$} & \multicolumn{3}{|c|}{ 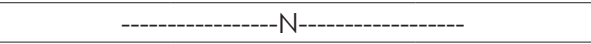 } & \multicolumn{3}{|c|}{ 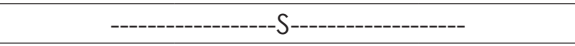 } \\
\hline & Leaf & Stem & Root & Leaf & Stem & Root \\
\hline & \multicolumn{6}{|c|}{-------------------------------------------------'g Kg } \\
\hline$N^{(a)}$ & $346.2^{*}$ & $5.72^{* *}$ & $127.3^{\text {ns }}$ & $16.81^{* *}$ & $12.09^{* *}$ & $11.06^{*}$ \\
\hline$S^{(b)}$ & $4.47^{\text {ns }}$ & $0.70^{\text {ns }}$ & $1.24^{\mathrm{ns}}$ & $0.66^{\mathrm{ns}}$ & $0.40^{\text {ns }}$ & $28.53^{* *}$ \\
\hline$N \times S^{\left(a^{*} b\right)}$ & $171.6^{\text {ns }}$ & $1.76^{\text {ns }}$ & $491.9^{\text {ns }}$ & $3.48^{\text {ns }}$ & $13.84^{* *}$ & $7.40^{\text {ns }}$ \\
\hline CV (\%) & 23.2 & 22.48 & 26.48 & 9.43 & 21.41 & 13.31 \\
\hline \multirow{3}{*}{$\begin{array}{c}\text { Sources of } \\
\text { variation }\end{array}$} & \multicolumn{3}{|c|}{ 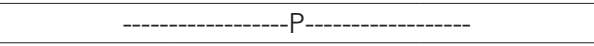 } & \multicolumn{3}{|c|}{ 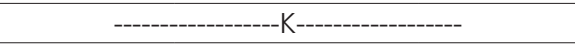 } \\
\hline & Leaf & Stem & Root & Leaf & Stem & Root \\
\hline & \multicolumn{6}{|c|}{ - } \\
\hline$N^{(a)}$ & $0.11^{* *}$ & $0.16^{\text {ns }}$ & $0.15^{\text {ns }}$ & $4.42^{\text {ns }}$ & $9.31^{\mathrm{ns}}$ & $70.79^{*}$ \\
\hline$S^{(b)}$ & $0.12^{\text {ns }}$ & $0.28^{\text {ns }}$ & $0.52^{\mathrm{ns}}$ & $0.20^{\text {ns }}$ & $5.60^{\text {ns }}$ & $8.84^{\text {ns }}$ \\
\hline$N \times S^{\left(a^{*} b\right)}$ & $0.16^{\text {ns }}$ & $0.10^{\text {ns }}$ & $0.19^{\text {ns }}$ & $4.84^{\mathrm{ns}}$ & $23.53^{\text {ns }}$ & $21.09^{\text {ns }}$ \\
\hline CV (\%) & 12.86 & 22.5 & 20.13 & 12.86 & 22.5 & 24.18 \\
\hline
\end{tabular}

The concentrations of $\mathrm{N}$ in leaves and stem in rosemary plants were significantly higher $(p \leq 0.05$ and 0.01 ) in the treatment of $420 \mathrm{mg} \mathrm{L}^{-1} \mathrm{~N}$ and $64 \mathrm{mg} \mathrm{L}^{-1} \mathrm{~S}$, when compared with doses $105 \mathrm{mg} \mathrm{L}^{-1} \mathrm{~N}$ and $32 \mathrm{mg} \mathrm{L}^{-1}$ of $S$, with a reduction of $53.6 \%$ for the leaves and $78 \%$ in the stem. These results indicate that with the increase of the $\mathrm{N}$ and $\mathrm{S}$ ratio, there was greater absorption and assimilation of $\mathrm{N}$ in these components. On the other hand, it is verified that in the roots the $\mathrm{N}$ concentration was not influenced by the concentrations of $S$ applied (Table 6).

Considering that rosemary plants are not extracted from the soil, being collected periodically, these results indicate that in soils with low availability of $S$, the assimilation of $\mathrm{N}$ will not be impaired in the formation of organic compounds such as amino acids and proteins in the roots.

The results obtained with the rosemary plants for the $\mathrm{N}$ content indicate that although there was no significant difference in the interaction, there was a greater assimilation of $\mathrm{N}$ at the highest dose of $\mathrm{S} 64 \mathrm{mg} \mathrm{L}^{-1}$ used, corresponding to a ratio of 6:5.

For the levels of $S$ in rosemary plants, all components obtained significant differences depending on the doses of $\mathrm{N}$ used. 
Table 6. Concentrations of nitrogen (N) and sulfur (S), in leaf, stem, and root in the plant Alecrim (Rosmarinus officinalis L.) cultivated with different doses of nitrogen and sulfur in Cruz das Almas-BA, 2019.

\begin{tabular}{|c|c|c|c|c|c|c|}
\hline \multirow{3}{*}{ Doses of $\mathrm{N}$ and $\mathrm{S}$} & \multicolumn{3}{|c|}{ 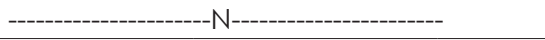 } & \multicolumn{3}{|c|}{ 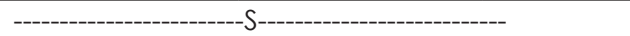 } \\
\hline & Leaf & Stem & Root & Leaf & Stem & Root \\
\hline & \multicolumn{6}{|c|}{ - } \\
\hline 105:64 & $2.78 a b$ & $1.25 \mathrm{~b}$ & $1.05 \mathrm{a}$ & $0.013 \mathrm{ab}$ & $0.05 a$ & $0.011 \mathrm{ab}$ \\
\hline 105:32 & $2.14 \mathrm{~b}$ & $1.46 \mathrm{~b}$ & $1.10 a$ & $0.011 \mathrm{~b}$ & $0.02 \mathrm{~b}$ & $0.010 \mathrm{bc}$ \\
\hline $210: 64$ & $2.99 \mathrm{ab}$ & $1.64 \mathrm{~b}$ & $1.15 \mathrm{a}$ & $0.014 a b$ & $0.02 \mathrm{~b}$ & $0.011 \mathrm{abc}$ \\
\hline $210: 32$ & $3.19 a b$ & $0.82 \mathrm{~b}$ & $1.20 \mathrm{a}$ & $0.016 a$ & $0.02 \mathrm{~b}$ & $0.012 a b$ \\
\hline 315:64 & $3.92 \mathrm{ab}$ & $1.65 \mathrm{~b}$ & $1.34 \mathrm{a}$ & $0.016 \mathrm{a}$ & $0.02 \mathrm{~b}$ & $0.014 a$ \\
\hline 315:32 & $3.33 \mathrm{ab}$ & $2.39 a b$ & $1.45 \mathrm{a}$ & $0.015 a b$ & $0.06 a$ & $0.012 \mathrm{ab}$ \\
\hline 420:64 & $4.64 a$ & $3.74 a$ & $1.38 \mathrm{a}$ & $0.016 a$ & $0.05 a$ & $0.013 a b$ \\
\hline $420: 32$ & $3.30 \mathrm{ab}$ & $2.42 \mathrm{ab}$ & $1.57 \mathrm{a}$ & $0.015 a b$ & $0.05 a$ & $0.009 \mathrm{c}$ \\
\hline
\end{tabular}

In the leaf component, the lowest concentrations of $105 \mathrm{mg} \mathrm{L}^{-1} \mathrm{~N}$, even increasing the dose of $\mathrm{S}$, its assimilation by the leaves did not increase. It can also be inferred that in the lowest concentration of $32 \mathrm{mg}$ $\mathrm{L}^{-1}, \mathrm{~N}$ was better assimilated when available in the dose of $210 \mathrm{mg} \mathrm{L}^{-1}$, however, in doses higher than this it was found that there was no influence on the assimilation of S. For the stem component, it was observed that in low concentrations of $\mathrm{N}$ there was a greater assimilation of $\mathrm{S}$, demonstrating a greater efficiency of assimilation of $\mathrm{S}$.

In the root component, the absorption and assimilation of $\mathrm{S}$ was higher in the dose $315 \mathrm{mg} \mathrm{L}^{-1}$ of $\mathrm{N}$ with $64 \mathrm{mg} \mathrm{L}^{-1}$ of $S$, differing only for the treatment 420 $\mathrm{mg} \mathrm{L}^{-1}$ of $\mathrm{N}$, it was observed that the assimilation of $\mathrm{S}$ was higher when it was supplied in the largest amount at 64 $\mathrm{mg} \mathrm{L}^{-1}$. This implies that soils rich in organic matter or that receive high doses of nitrogen fertilizers are necessary for the application of $S$ for its greater efficiency of absorption by the roots.

Davidian \& Kopriva (2010) explained that when extracted from the soil by plants, $S$ in the form of sulfate is assimilated or transiently stored in vacuoles of roots or leaves. This fact was observed by Girondé et al. (2014), when evaluating the impact of sulfur restriction on seed yield and quality and redistribution of this element on the components of Brassica napus L. plants. They found that a large part of the assimilated sulfur was allocated to the roots, explaining the greater dry matter weight gain in this organ when compared to other treatments.

When studying the responses of crops and availability of $S$ in soils with different levels of clay and organic matter submitted to sulfated fertilization, Tiecher et al. (2012) found that the amount of $S$ in the aerial part of plants and the content of $S$ available in the soil increased with the application of the nutrient.

Several plant compounds have both $\mathrm{N}$ and $S$, which helps to explain the existence of an $\mathrm{N}$ and $\mathrm{S}$ relationship that are linked to growth and production (Malavolta \& Moraes, 2007). Cruciol et al. (2006) affirmed that when there is a limitation in the supply of $S$, the application of high doses of other nutrients in plants, mainly $\mathrm{N}, \mathrm{P}$ and $\mathrm{K}$, result in low productivity, due to imbalances in the N/S and $P / S$ ratios, respectively.

According to Jamal et al. (2010) the interaction between $\mathrm{N}$ and $\mathrm{S}$ is directly related to the changes and physiological responses of plants, studies on this relationship can assist in fertilization recommendations, which will vary according to the crop.

Thus, establishing a balanced $\mathrm{N}$-and-S relationship for crops is necessary. It is noteworthy that even these elements have a strong inter-relationship of absorption and assimilation, studies of the relationship are scarce for most crops, especially for medicinal plants such as rosemary.

\section{Conclusions}

There was no significant interaction for the doses of $\mathrm{N}$ and $\mathrm{S}$ in most of the evaluated agronomic characteristics, except for root dry matter mass.

The increase in $\mathrm{N}$ doses promoted the highest concentrations of this nutrient in the leaf and in the stem regardless of the $S$ doses used.

The efficiency of sulfur assimilation in the leaf and stem components increases when $\mathrm{N}$ is in high concentrations.

The assimilation of $\mathrm{S}$ by the rosemary plants is dependent on the availability of $\mathrm{N}$ in the soil.

\section{References}

Alvares, C.A., Clayton, A., Stape, J.L., Sentelhas, P.C., Moraes, G., José, L. 2013. Sparovek, Gerd. Köppen's Climate Classification Map for Brazil. Meteorologische Zeitschrift 22: 711-728.

Benincasa, M.M.P. 2004. Análise de crescimento de plantas: noções básicas. Funep, Jaboticabal, Brazil. 42 p.

Binotti, F. S., Arf, O., Cardoso, E. D., Sá, M.E., Buzetti, S., Nascimento, V. 2010. Fontes e doses de nitrogênio em cobertura no feijoeiro de inverno irrigado no sistema plantio direto. Bioscience Journal 26: 770-778. 
Bonfim-Silva, E.M., Monteiro, F.A., Silva, T.J.A. 2007. Nitrogênio e enxofre na produção e no uso de água pelo capim-braquiária em degradação. Revista Brasileira de Ciência do Solo 31: 309-317.

Cantarella, H. Nitrogênio. 2007. In: Novaes, R.F., Alvarez, V.V.H., Barros, N.F., Fontes, R.L.F., Cantarutti, R.B., Neves, J.C.L. (Ed.) Fertilidade do solo. Sociedade Brasileira de Ciência do Solo, Viçosa, Brazil. p. 375-470.

Ciriello, V., Guerrini, I.A., Backes, C. 2014. Doses de nitrogênio no crescimento inicial e nutrição de plantas de guanandi. Cerne 20: 653-660.

Crusciol, C.A.C., Soratto, R.P., Silva, L.M., Lemos, L.B. 2006. Aplicação de enxofre em cobertura no feijoeiro em sistema de plantio direto. Bragantia 65: 459-465.

Davidian, J.C, Kopriva, S. 2010. Regulação da captação e assimilação de sulfato - iguais ou não iguais? Molecular Plant 3: 314-325.

Ehlert, P.A.D., Ming, L.C., Marques, M.O.M., Fernandes, D.M., Rocha, W.A., Luz, J.M.Q., Silva, R.F. 2013. Influência do horário de colheita sobre o rendimento e a composição do óleo essencial de erva-cidreira brasileira [Lippia Alba (Mill.) NE Br.]. Revista Brasileira de Plantas Medicinais 15: 72-77.

Ericsson, L.O., Ronge, B. 2006. Sistema Brasileiro de Classificação de Solos. 2. ed. Embrapa Solos, Rio de Janeiro, Brazil. 306 p.

Faithfull, N.T. 2002. Methods in agricultural chemical analysis: a practical handbook. CABI Publishing Wallingford, UK. 262 p.

Ferreira, D.F. 2008. Sisvar: um programa para análises e ensino de estatística. Revista Symposium 6: 36-41.

Freitas, J.C.D.O., Almeida, A.A.F.D., Fragassi Lago, M., Souza, M.M.D. 2012. Características morfofisiológicas de plantas clonais de Passiflora alata crescidas em diferentes doses de nitrogênio e níveis de sombreamento. Revista Brasileira de Fruticultura 34: 859-872.

Girondé, A., Dubousset, L., Trouverie, J., Etienne, P. Avice, J.C. 2014. The impact of sulfate restriction on seed yield and quality of winter oilseed rape depends on the ability to remobilize sulfate from vegetative tissues to reproductive organs. Frontiers in Plant Science 5: 695.

Hoagland, D.R., Arnon, J.P. 1950. The water culture method for growing plants without soils. California Agricultural Experimental Station, Berkeley, USA. 347 p.

Jamal, A., Moon, Y.S., Abdin, M.Z. 2010. Sulphur - a general overview and interaction with nitrogen. Australian Journal of Crop Science 4: 523-529.

Jones, J.B. 2001. Laboratory guide for conducting soil tests and plant analysis. CRC Press, Boca Raton, USA. 384 p.

Liu, S., Hongju, H., Feng, G., Chen, Q. 2009. Effect of nitrogen and sulfur interaction on growth and pungency of different pseudostem types of Chinese spring onion
(Allium fistulosum L.). Scientia Horticulturae 121: 12-18.

Lorenzi, H., Matos, F.J. 2006. Plantas Medicinais no Brasil: Nativas e Exóticas Cultivadas. 1. ed. Instituto Plantarum LTDA, Nova Odessa, Brazil. 512 p.

Malaquias, G., Cerqueira, G.S., Ferreira, P.M.P., Pacheco, A.C.L., Souza, J.M.C., Deus, M.S.M., Peron, A.P. 2014. Utilização na medicina popular, potencial terapêutico e toxicidade em nível celular das plantas Rosmarinus officinalis L., Salvia officinalis L. e Mentha piperita L. (Família Lamiaceae). Revista Intertox de Toxicologia, Risco Ambiental e Sociedade 7: 50-68.

Malavolta, E., Moraes, M.F. 2007. Fundamentos do nitrogênio e do enxofre na nutrição mineral das plantas cultivadas. In: Yamada, T., Abdalla, S.R.A., Vitti, G.C. (Ed.). Nitrogênio e enxofre na agricultura brasileira. International Plant Nutrition Institute, Piracicaba, Brazil. p. 189-249.

Marschner, H. 2012. Mineral nutrition of higher plants. 3. ed. Elsevier, London, UK. 651 p.

Mastuscello, J., Ribeiro, Y., Braz, T., Ferreira, M., Assis, J., Jank, L., Reis, G. 2018. Produção de forragem, morfogênese e eficiência agronômica do adubo em capim BRS Quênia sob diferentes doses de nitrogênio. Boletim de Indústria Animal 75: 1-12.

May, A., Suguino, E., Martins, N.A., Pinheiro, Q.M. 2010. Produção de biomassa e óleo essencial de Mentha citrata em função do manejo cultural e adubação nitrogenada. Revista Brasileira de Ciências Agrárias 5: 370-375.

Peixoto, P.C., Cruz, V.T., Peixoto, M.F.S.P. 2011. Análise quantitativa de crescimento de plantas. Enciclopédia Biosfera 7: 51-76.

Rašković, A., Milanović, I., Pavlović, N., Cebovic, T., Vukmirovic, S., Mikov, M. 2014. Antioxidant Activity of Rosemary (Rosmarinus officinalis L.) Essential Oil and its Hepatoprotective Potential. BMC Complementary and Alternative Medicine 14: 225.

Silva, F.C.S 2009. Manual de análises químicas de solos, plantas e fertilizantes. Embrapa Solos, Rio de Janeiro, Brazil. $627 \mathrm{p}$.

Silva, M.L.S., Trevizam, A.R. 2015. Interações iônicas e seus efeitos na nutrição das plantas. Informações Agronômicas 149: 10-16.

Silva, P.W., Bonfim, S.E.M., Schlichting, A.F., Silva, M.C. 2013. Desenvolvimento inicial de trigo sob doses de nitrogênio em Latossolo Vermelho de Cerrado. Revista Brasileira de Engenharia Agrícola e Ambiental 17: 575-580.

Silveira, C.P., Oliveira, D.A., Bonfim-Silva, E.M., Monteiro, F.A. 2011. Two years of nitrogen and sulfur fertilizations in a signal grass pasture under degradation: changes in the root system. Revista Brasileira de Zootecnia 40: 1195-1203.

Stipp, S.R., Casarin, V. 2010. A importância do enxofre na agricultura brasileira. IPNI, Piracicaba, Brazil. p. 14-20. 
Taiz, L., Zeiger, E., Moller, I.M., Murphy, A. 2017. Fisiologia e desenvolvimento vegetal. Artmed, Porto Alegre, Brazil. $858 \mathrm{p}$.

Tiecher, T., Rheinheimer, S.D., Rasche, A.W.J., Brunetto, G., Mallmann, K.J.F., Piccin, R. 2012. Resposta de culturas e disponibilidade de enxofre em solos com diferentes teores de argila e matéria orgânica submetidos à adubação sulfatada. Bragantia 71: 518-527.

Weatherburn, M.W. 1967. Phenol-hypochlorite reaction for determination of ammonia. Analytical Chemistry 39: 971-974.

Conflict of Interest Statement: The authors declare that the research was conducted in the absence of any commercial or financial relationships that could be construed as a potential conflict of interest.

All the contents of this journal, except where otherwise noted, is licensed under a Creative Commons Attribution License attribuition-type BY. 